IRA International Journal of Education and Multidisciplinary Studies ISSN 2455-2526 Vol. 03 Issue 02 (May, 2016)

Paper DOI: https://dx.doi.org/10.21013/jems.v3.n2.p5

\title{
Festival Related Burns Managed in a Tertiary Burn Care Centre
}

\author{
Dr. Angeline Selvaraj M.S, M.Ch. \& Prof. Nirmala Ponnambalam M.S, M.Ch. \\ Department of Burns, Plastic \& Reconstructive Surgery, Government Kilpauk \\ Medical College Hospital, Chennai.
}

\begin{abstract}
Fire is considered sacred and forms an integral part of all festivals that are celebrated in India. Fire related injuries during festivals cause a lot of morbidity, mortality and a sense of grief to the family members. Burns unit of Government Kilpauk Medical College hospital in Chennai is a tertiary burn centre with referrals from all over Tamil Nadu Andhra Pradesh and Karnataka. Festival related Bhogi burns, Fire walk, Deepavalifire work injuries and Karthigaideepam lamprelated burns were analyzed for a period of one year from January 2015 to December 2015. The demographic profile, peculiarities of the distribution of burns and outcome were studied to enhance the awareness ofthe dangers associated with these festival practices and be prepared to deal with the increasing patient load during these festivals.
\end{abstract}

Key words: Bhogi, Fire walk, Deepavali,KarthigaiDeepam, lamp/fireworks burns

\section{Introduction:}

Festivals are times of celebration Most Indian festivals have fire related event as a mark of worshipping fire which is considered sacred. Fireworks used during these occasions make the festival colourful and bright. Though the festivals are celebrated by all, the fire related accidents are found to show more preponderance to certain age group and sex distribution. Government Kilpauk Medical college Hospital has a 50 bedded burn unit catering to Tamilnadu, Pondicherry and neighboring states. As a tertiary burn care centre, this burn unit has a wide range of patient admissions. Hence an analysis of festival related burns was planned, to study the demographic

The journal is a publisher member of Publishers International Linking Association Inc. (PILA)-Crossref (USA). (C Institute of Research Advances : http://research-advances.org/index.php/IJEMS 
profile, incidence and outcome. Though fire walk and firework injuries have been studied and presented, there are no earlier studies about burns occurring during Bhogi and Karthigai Deepam.

\section{Materials and Methods:}

2.1.Materials:All inpatients, who were admitted in the burns unit of Government Kilpauk Medical college hospital during the period of January 2015 to December 2015, were included in this retrospective study.

The following details were obtained from all the admitted patients-

- Name, age and sex

- Occupation and address

- The date and time of the incident

- The place where the incident happened

- Distribution of burns in the body and total body surface area(BSA) burnt.

The patients who were suffering from co-morbid conditions like diabetes mellitus, heart diseases, seizure disorders etc were evaluated for the co morbid conditions.

The patients had the weight and BSA assessed and intravenous fluids were transfused as per modified Parkland formula of $3 \mathrm{ml} / \mathrm{Kg} / \mathrm{BSA}$ burns for the first 24 hours. Antibiotics and analgesics were given. Dressings using antiseptic creams were done.

As a routine the following biochemical tests were done- Complete haemogram, blood sugar,renal function tests, liver function tests, assay of HIV, antibodies to hepatitis B virus. Blood grouping and $\mathrm{Rh}$ typing was done and plasma was transfused on second post burn day.Surface swabs from burn wounds were taken on third post burn day and were repeated periodically. Blood culture was done when there was an indication of septicemia. Superficial wounds were covered with collagen sheets.Deep burns, burns over face hands and genitalia were routinely dressed with silver sulphadiazine ointment dressings which were changed periodically.When there were deep burn wounds which did not heal after two weeks or showed granulations, skin grafting was done after a thorough debridement .

\subsection{Festival Related Burns:}

2.2.1. BHOGHI BURNS: Bhoghi is a festival celebrated in the middle of January marking the beginning of the Tamil month ofThai. It is customary to burn old unwanted items to make way for new. Burns that occurred during this event were studied.

The journal is a publisher member of Publishers International Linking Association Inc. (PILA)-Crossref (USA). ( ) Institute of Research Advances : http://research-advances.org/index.php/IJEMS 


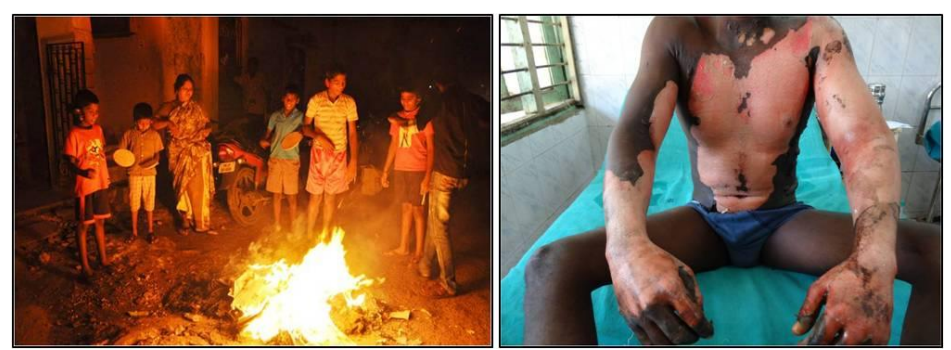

Figure 1: The Bhogi custom of burning the old, and a patient with bhogi 'burn'.

2.2.2. FIRE WALK: $A A D I$ FIREWALK is a ritual which is usually practiced near the Hindu temples in the month of Aadi, which corresponds to the latter half of July and first half of August. Devotees walk on hot coal bed to fulfill a vow. While running across the hot coal bed, people are jostled and tendto fall down, sustaining burns. Sometimes, when children are carried by the elders ${ }^{[1]}$ as a part of the vow fulfillment, they also sustain burns. The characteristics of the burns in such patients, is the presence of speckled pattern of contact burns with varying depths. These burns were typically seen on the sides and back of the limbs and trunk.

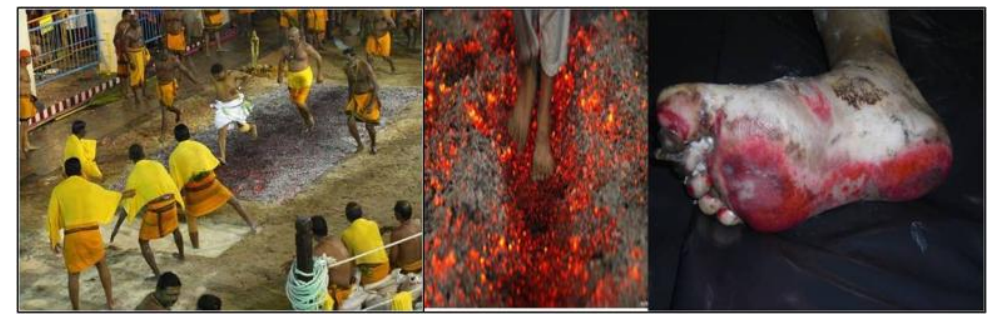

Figure 2: The Fire walk ritual and the typical burns caused.

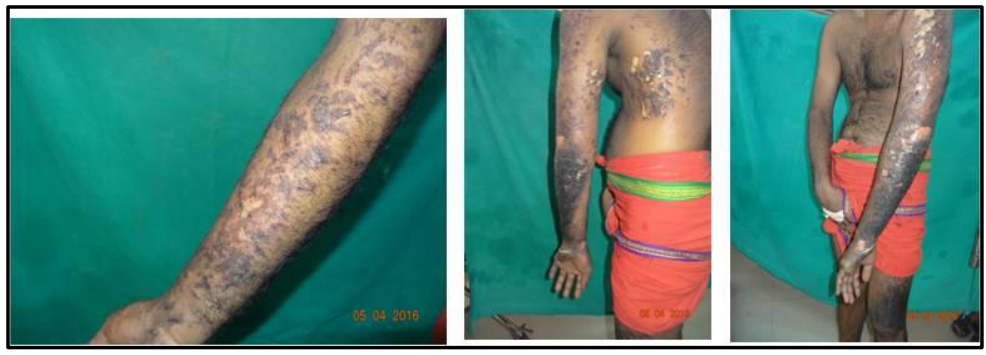

Figure 3: Characteristic patterns of fire walk burns

2.2.3. DEEPAVALI FIRE WORKS: Deepavalibeing a festival of lights is celebrated by bursting crackers ${ }^{[6]}$ and fire accidents are very common ${ }^{[4]}$. The age and sex distribution along with the type of cracker involved has been studied.

The journal is a publisher member of Publishers International Linking Association Inc. (PILA)-Crossref (USA). ( ) Institute of Research Advances : http://research-advances.org/index.php/IJEMS 

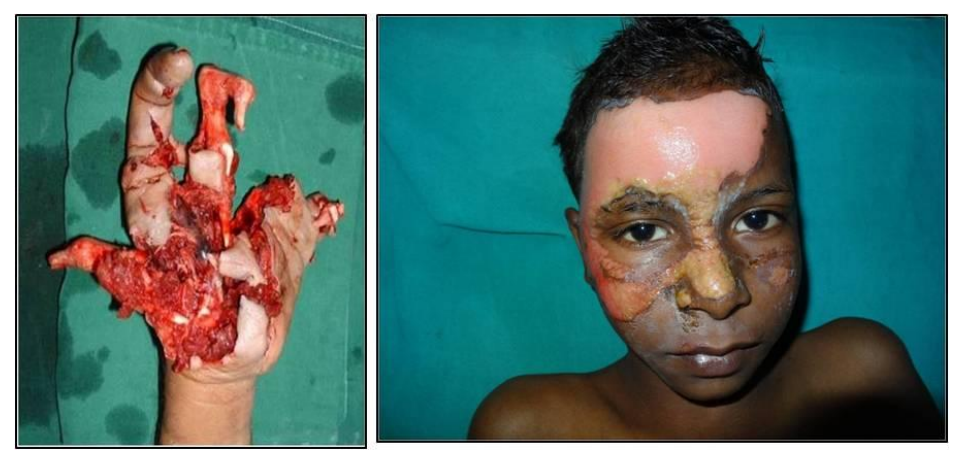

Figure 4: A typical Cracker burst injury of the hand, and cracker burns on the face

2.2.4.KARTHIGAIDEEPAM BURNS: Lighted lamps are kept on beautifully drawn kolams (drawings on the floor). These lamps are kept on the floor, foot paths, staircases and compound walls in the Tamil month of Karthigaicorresponding to November/ December. Very young or very old people walk unaware of the proximity of fire and the clothes catch fire. Due to slow reflexes of these persons, the time taken to put out fire is longer. Hence the extentof burns is more.

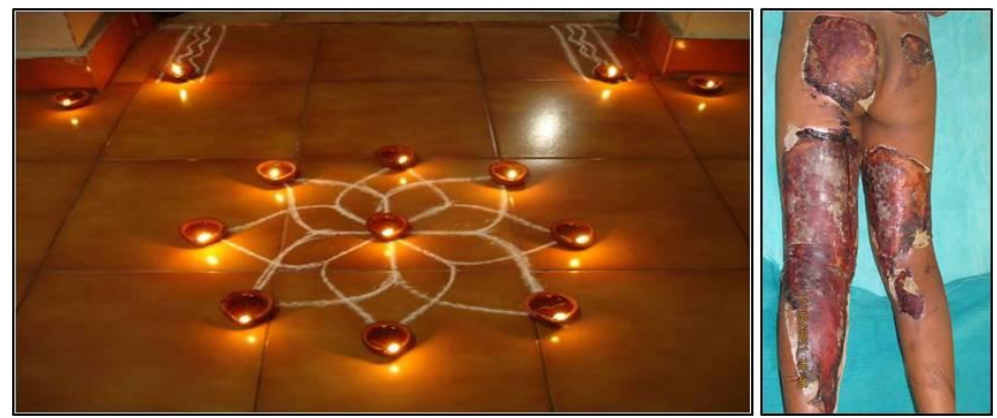

Figure 5: The decorations on the floor with lighted lamps, and the charecteristic burns caused.

\section{0bservations:}

3.1Total admissions in the burns unit were 1743 in the period studied.

The total number of festival related burns were 87.

3.1.1 There was one Bhogi burn, fire walk burns were 9, cracker related burns were 43 , and 34 patients were admitted due to KarthigaiDeepam burns. There were many smaller percentage burns who were treated as outpatients and hencewere not included in this study.

3.2.Sex distribution: Males affected in festival burns were 51, females were 36 .

The journal is a publisher member of Publishers International Linking Association Inc. (PILA)-Crossref (USA). ( I Institute of Research Advances : http://research-advances.org/index.php/IJEMS 
3.3Age distribution: the lowest age of festival related burn victim was 2 years and the oldest was 92 years old.

\subsection{Analysis of type of burn:}

3.4.1.Bhoghi burn: One adult male was admitted with $27 \%$ BSA burn.

3.4.2.Fire walk burn: There were 9 admissions with fire walk burns. There were 7 males, 1 female and 1 child. BSA of burns ranged from $9 \%$ to $40 \%$.One male with $27 \%$ burns succumbed due to co morbid illness.

3.4.3.Cracker burns of deepavali: There were 43 admissions due to fire works related burn injuries. 40 patients were male and 2 patients were female and 1 patient was a female child. The 2 females were bystanders.

3.4.4.Karthigai deepam burns: There were 34 admissions with lamp related burns. Age group ranged from 2 years to 93 years. Deepam burns in pediatric age group was 8. Females affected in the geriatric age group were 12.3 male patients were affected. 3.5. BSA of festival burns.

3.5.1.BSA of burns due to lamp was from $6 \%$ to $92 \% .12$ patients who expired were in the extremes of age, and had co-morbid illness.

3.5.2.BSA of festival burns: BSA burnt in cracker blast injury was $1 \%$ to $20 \%$ Even $1 \%$ BSA burns was admitted as the patient needed debridement and skin cover.

3.6.1.Type of fire work: Flower pots were the commonest cause of fire work related burns followed by burning of the powder of the crackers. Country made fireworks resulted in maximum number of blast injuries, which required multiple surgeries.

3.7.Distribution of burns: Face and hands were commonly affected in firework burns and lower limbs and trunk were affected in Deepam burns and firewalk burns.

\section{Discussion:}

The incidence of the festival burns shows that there is greater chance of males being victims in Bhoghi, Fire walk and Cracker burns.There was a specific female preponderance in KarthigaiDeepam burns. The extremes of age group(paediatric \& geriatric)were involved in KarthigaiDeepam burns. Cracker burnsinvolvedmore of pediatric age group.BSA affected was mostly less than $40 \%$, except in KarthigaiDeepam burns. The outcome depended on the percentage of burns, comorbid illness and age of the patient[2]. Elderlypatients had associated co-morbid illnesses leading to prolonged hospital stay and developedmore complications. Hence

The journal is a publisher member of Publishers International Linking Association Inc. (PILA)-Crossref (USA). ( Institute of Research Advances : $\underline{\text { http://research-advances.org/index.php/IJEMS }}$ 
mortality was also higher in these patients. Except in lamp related burns, the body surface area involved was less than $40 \%$. The distribution of burns was in the lower limbs and the back, inKarthigaiDeepam burns, and in patches or speckled areas of contact in fire walk. Pediatric age group affected in fire walk were either due to being carried by adults and dropped accidentally, when rushing through the hot coal or pushed by the crowd and falling on the hot coal. Seasonal increase in the number of burn victims was noted with these events. There are no study reports of burns due to the Deepamor Bhoghi fire. This may be because these events are mostly regional and are celebrated in different names,in different places.

\section{Conclusion:}

All the festivals in Tamilnadu have a fire related event. Increased number of accidents are reported in patients following these celebrations. More number of malesareaffected following Bhoghi burn, cracker blasts or fire walk. Lamp related burns are common in females. Involvement of burns in extremes of ages is also seen in burns due to KarthigaiDeepam. The type of garments worn in the very young children and old women are the cause for these mishaps (long/ loosegarments) ${ }^{[3]}$.Absence of regulatory authorities in the sites of festivals cause mayhem and accidents. Enforcement of stringent rules in conducting the public events can prevent accidents. A preliminary medical examination to assess the fitness of individuals before they resort to dangerous activities like fire walk can be implemented to avoid people with co morbid illness in participating in such events. Fireworks are to be displayed[5] in safe zones only. It should be made mandatory that prior permission be obtained to carry out fireworks during funerals or temple festivals. Unauthorized firework is to be banned so that accidents are prevented. Awareness programs are to be conducted in schools, colleges and offices. Media like newspapers, magazines, radio stations and television channels can create awareness about these festival related burns and give details about preventive measures. Awareness is the key to prevention.

\section{DECLARATION}

There is no financial support from any source for this study and there is no conflict of interest.

\section{References}

1. Profile of Pediatric Burns: Indian Experience in a tertiary care burn unit; Mathangi Ramakrishnan. K.,Sankar.J..Jayaraman.V. Burns, 2005:31;351-353.

2. Davis JWL The Problem of Burns in India. Burns1990:16(suppl I).

3. Mc Loughlin E, Simple guide to burns prevention.Burns1995:21;217-20.

The journal is a publisher member of Publishers International Linking Association Inc. (PILA)-Crossref (USA). (C) Institute of Research Advances : http://research-advances.org/index.php/IJEMS 
4. Chammana Shoba, Mukerjee.g., PathidarGp Gupta S.: Epidemiology of Pediatric burns in Indore, India, Burns2001:27:33-38.

5. Ching Chiran Liao, Annette Mackay Rossignol: Landmarks in Burns Prevention:Burns:26:422-34.

6. Annals of Burns and fire disasters Vol.xxiii no:1 March2010.8-18. 